\section{From Tragedy to} Triumph-Rebuilding Green Buildings after Disaster

\section{About Green Buildings}

Green buildings save thousands in utility bills while making the indoor environment healthier and more comfortable for occupants. According to the U.S. Green Building Council, green commercial and public buildings on average use up to $50 \%$ less energy, emit up to $40 \%$ less $\mathrm{CO}_{2}$, consume $40 \%$ less water, and produce $70 \%$ less solid waste. Green commercial buildings encourage the use of energy efficiency features such as effective insulation, highperformance windows, tight construction, and energy-efficient lighting, office equipment, and heating and cooling systems. Green buildings are healthier because they perform better and protect occupants against cold, heat, drafts, moisture, indoor pollutants, and noise.

Green buildings encourage the use of renewable energy to reduce a building's impact on the environment. A variety of renewable technologies are available, including small wind energy systems, geothermal heating and cooling, and solar energy systems. The most common form of renewable energy used on commercial and public buildings is solar energy. In areas with frequent storms or after a natural disaster, renewable energy can provide emergency power if batteries are integrated into the system.

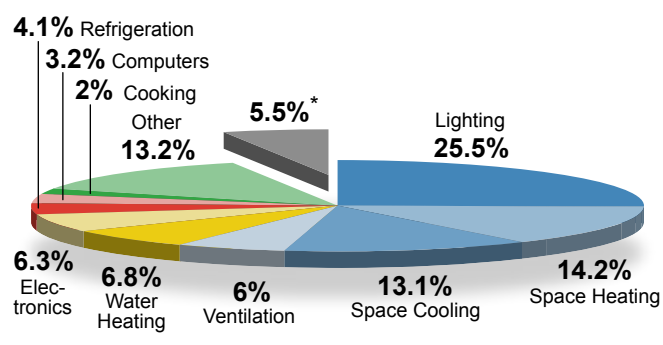

\section{Green Benefits to} the Community

- Stimulates local economies

- Restores community pride

- Promotes cleaner environment.

How Commercial Buildings Use Energy

Rebuilding a business and community after a natural disaster such as a flood, hurricane, or tornado can be daunting. Turn a tragedy into an opportunity to create a healthier, more comfortable, and more energy-efficient business or public office by rebuilding "green."

\section{Renewable Energy Benefits}

- Generates electricity from the sun or wind

- Heats and cools quietly and naturally

- Grants tax credits to building owners

- Offers protection against rising utility bills

- Supplies reliable power after natural disasters

- Protects the environment. 


\section{Rebuilding Green in Greensburg}

After a tornado devastated their town in May 2007, the citizens of Greensburg, Kansas, turned disaster into opportunity by rebuilding as

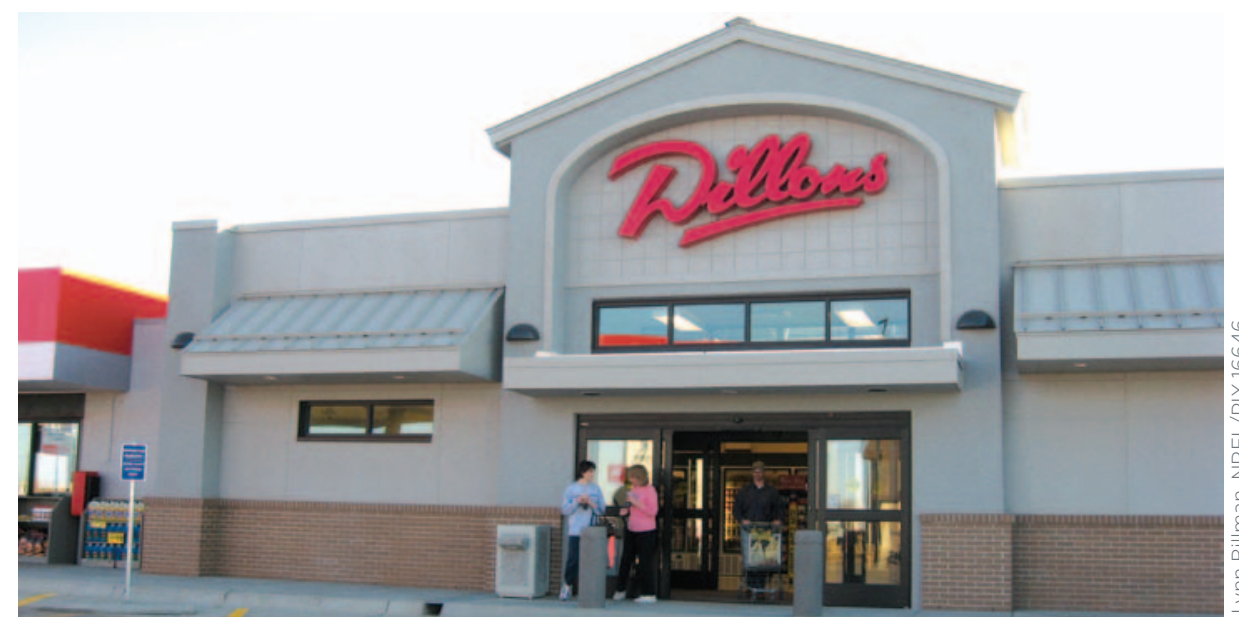

The Dillons grocery store in Greensburg, Kansas, hopes to set a new energy efficiency standard for rural grocery stores.

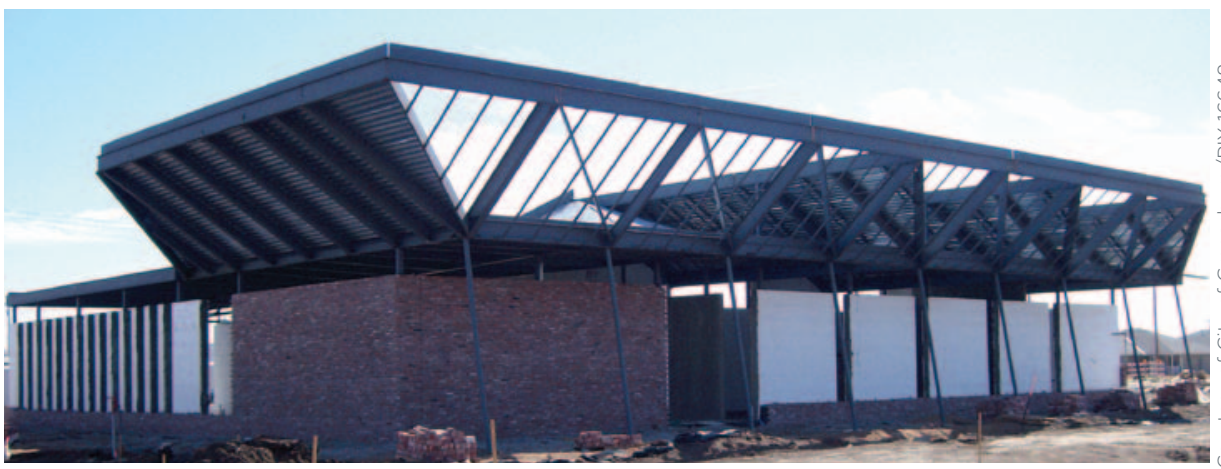

Greensburg's new City Hall will include solar panels and geothermal technology, and will be built out of reclaimed brick and recycled wood and materials.

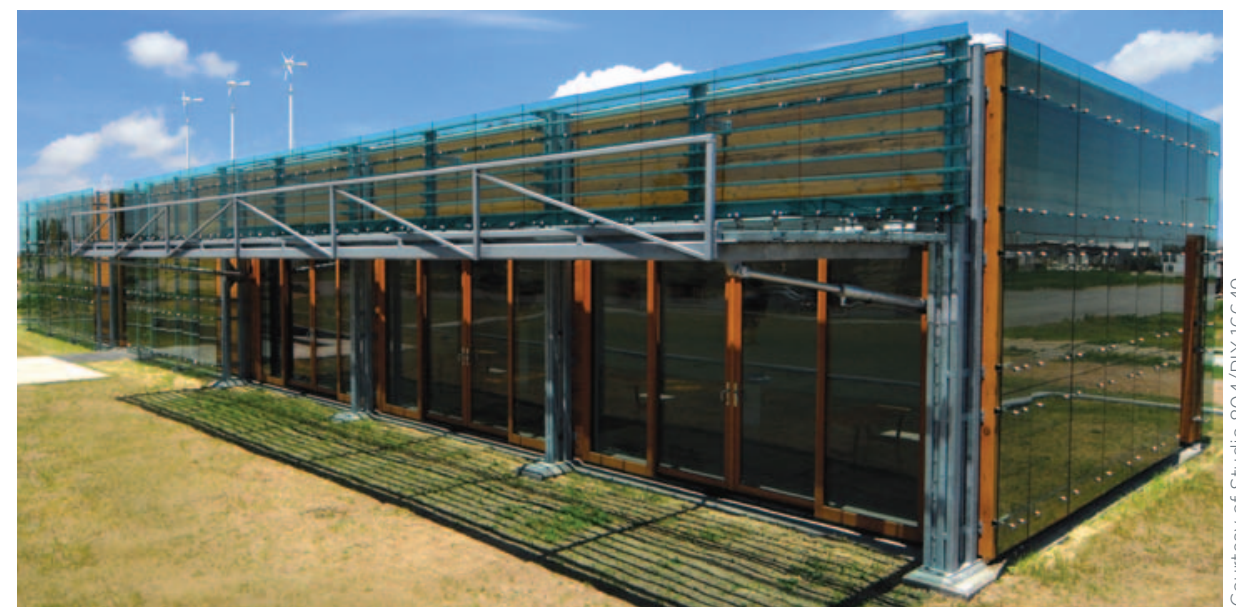

The 5.4.7. Arts Center in Greensburg, named after the May 4, 2007, tornado that destroyed most of town, is the first LEED Platinum building in Kansas. certification. LEED Platinum buildings use much less energy than similar conventional buildings.

\section{Dillons Grocery Store}

Completed in February 2009, the new Dillons is a hybrid between a grocery store and a gas station. The building includes a number of unique green building features such as an insulated concrete wall system, skylighting, LED lighting, and high efficiency refrigeration and HVAC equipment.

\section{BTI-Greensburg John Deere}

The John Deere farming equipment dealership in Greensburg is designed to LEED Platinum. Based on the lessons learned in Greensburg, additional John Deere dealerships are being built to maximize energy efficiency, and the company has redirected its business plan to promote energy efficient, green dealerships throughout North America. The Greensburg building includes green features such as a wellinsulated roof and walls, insulated high bay doors, skylights, light tubes, energy efficient lights and equipment, wind turbines, and recycled waste oil used for heating water.

\section{Green Public Buildings}

The City of Greensburg passed a resolution that all new city-owned buildings would be LEED Platinum, including their City Hall and Business Incubator buildings. The resolution has inspired other public and commercial buildings to strive for building designs that will reach LEED Platinum or Gold, including, the Kiowa County Memorial Hospital and the Kiowa County Courthouse.

\section{Greensburg School Complex}

This K-12 school is setting a new standard for sustainable building practices. Not only is the school campus designed to LEED Platinum standards, but the school is expanding its curricula on energy and green technologies to include "hands-on" educational experiences for the students. The high school students in Greensburg have enthusiastically 
supported the community's goals, and formed a "Green Club." Some sustainable features planned for the new school include:

- An optimized building envelope and outdoor classrooms to reduce heating, cooling, and lighting energy loads

- Ground source/geothermal heating and cooling systems

- Natural lighting and ventilation

- Indoor water control systems

- Electricity from an onsite wind turbine (tentative).

\section{Contact Information}

For more information about Greensburg, contact: (620) 549-3752 or (620) 723-2790

info@greensburggreentown.org

204 West Florida

Greensburg, KS 67054

To see case studies about Greensburg buildings, visit:

http://greensburg.buildinggreen.com

\section{Green Building Checklist}

Green construction methods can be integrated into buildings at any stage, but the most significant benefits result from using green methods in the earliest stages of a building project. Below is a checklist of basic green building features to discuss with your builder and architect.

\section{Energy Efficiency}

$\checkmark$ South and north orientation-Build facing due south to optimize solar heat gain as well as the efficiency of any renewable energy systems for producing electricity or heating water. Reducing east and west wall areas maximizes the energy efficiency of buildings with large cooling loads.

$\checkmark$ Daylighting-Install large windows that allow sunlight to reach about $75 \%$ of the interior to reduce the need for artificial lights. For small buildings with high heating loads, the extra sunlight can be used to heat concrete, tile, or brick flooring, which in turn can help heat the interior. Proper window overhangs will block the summer sun and reduce cooling loads. For large buildings with high cooling loads, large north windows will maximize daylight without increasing heat gain.

$\checkmark$ Efficient insulation-Capitalize on one of the easiest, most cost-effective ways to save energy by using efficient insulation for foundations, walls, and roofs. Usually, the higher the $\mathrm{R}$-Value of the insulation, the better it performs.

$\checkmark$ Energy-efficient windows and doorsLook for windows and doors with an ENERGY STAR ${ }^{\circledR}$ rating. Consider installing double-paned windows with a "low-e" glazing to hold in heat in winter and cool air in summer. Usually, the lower the U-Value, the better the performance.

$\checkmark$ Efficient water heating-Choose the most energy efficient water heating system you can, such as a tankless water heater, or consider installing solar water heating.

$\checkmark$ Energy-efficient heating and cooling system-Choose a $90 \%$ or greater efficiency furnace, a cooling system with an efficiency rating of SEER 14 (seasonal energy efficiency ratio) or higher (ENERGY STAR ${ }^{\circledR}$ is SEER 14), or a ground-source heat pump.

$\checkmark$ Programmable thermostat-Install a thermostat that automatically turns itself down at night to save energy.

$\checkmark$ Lighting technologies-Select lights that not only save energy, but also last much longer than traditional incandescent light bulbs, such as the compact fluorescent lights (CFLs) that have been easily available for some time. New technologies that use light-emitting diodes (LEDs) may also be an option. LED lamps illuminate at equivalent light levels to CFLs and can use less energy. An LED bulb can last for as many as 60,000 hours and a CFL for 10,000, compared to the incandescent's 1,500 . $\checkmark$ Occupancy sensors - Install sensors that turn off lights in unoccupied rooms such as conference rooms and bathrooms.

$\checkmark$ Appliances and Equipment-Install ENERGY STAR ${ }^{\circledR}$ appliances and office equipment to save energy.

\section{Water Efficiency}

$\checkmark$ Water-efficient fixtures and appliances-Reduce water and energy consumption (using less hot water also means using less energy) by installing low-flow sink and shower fixtures, toilets, and water-efficient dish and clothes washers.

$\checkmark$ Native landscaping-Reduce water consumption by choosing plants indigenous to your area and use drip irrigation when possible.

\section{Renewable Energy}

$\checkmark$ Solar electricity_Consider installing a small solar electric system on the roof to offset electrical loads.

$\checkmark$ Wind electricity-Small quiet wind energy systems are available for buildings in areas with sufficient open space.

$\checkmark$ Geothermal heating and cooling-The earth's natural temperature can be used to heat and cool your building using geothermal wells and a groundsource heat pump.

\section{Air Quality}

$\checkmark$ Nontoxic products-Use low volatile organic compound (VOC) paints and adhesives, and formaldehyde-free insulation.

$\checkmark$ Ventilation-Ventilate your building appropriately for a good supply of fresh air, without wasting energy on heating and cooling.

\section{Sustainable Building Materials and Construction}

$\checkmark$ Recycled materials - Select recycled or recycled-content materials such as carpet, countertops, paint, tile, and insulation. 
$\checkmark$ Sustainably harvested or reclaimed wood-Purchase wood certified by the Forestry Stewardship Council, reclaimed hardwood floors and siding, or use cork and bamboo flooring as alternatives.

$\checkmark$ Recycled construction waste - Try to recycle at least $50 \%$ of the wood, cardboard, and concrete from the project.

\section{Incentives for Energy Efficiency and \\ Renewable Energy}

Numerous financial incentives are available to help building owners make their buildings more energy efficient and to offset the cost of a renewable energy system. Among the incentives available are federal and state tax credits and utility rebates. Many utility companies also offer net metering for grid-connected systems, which gives building owners credit for excess energy produced by their systems. And the American Recovery and Reinvestment Act, signed into law on February 17, 2009 , contains provisions that will financially benefit businesses.

For more information about financial incentives, visit the Database of State Incentives for Renewables and Efficiency at www.dsireusa.org.

\section{Commercial Building Energy Alliances}

Partner members of these U.S. Department of Energy (DOE) alliances help guide research and encourage industry to move toward energy-efficient design and strategies in commercial buildings www.buildings.energy.gov/ commercial_initiative/alliances.html

\section{Retailer Energy Alliance} www.buildings.energy.gov/retailer/

\section{Hospital Energy Alliance} www.buildings.energy.gov/hospital/

\section{Commercial Real Estate Energy Alliance} www.buildings.energy.gov/real_estate/

\section{Green Building Resources Energy Savers}

Basic information about energy efficiency and renewable energy from DOE www.energysavers.gov

\section{ENERGY STAR ${ }^{\circledR}$}

This program of DOE and the U.S. Environmental Protection Agency helps building owners save energy and money through energy-efficient products and practices

www.energystar.gov

\section{Commercial Buildings Energy Efficiency Practices}

Guidelines from DOE for each step of the design and building process www.buildings.energy.gov/commercial/ index.html

\section{High-Performance Buildings Database}

Information from DOE about more than 100 high-performance buildings http://eere.buildinggreen.com/

\section{Green Building Case Studies}

A database of green commercial buildings from the U.S. Green Building Council (USGBC) www.usgbc.org/LEED/Project/ CertifiedProjectList.aspxb

\section{AIA Top Ten Green Buildings}

The American Institute of Architects (AIA) gives awards to the top ten green buildings www.aiatopten.org/hpb/index.cfm

\section{Green Schools Resources EnergySmart Schools}

Guidelines for building green schools from DOE

www.buildings.energy.gov/ energysmartschools/

\section{Green Schools Guide}

Guidelines for building green schools from USGBC http://www.buildgreenschools.org/

\section{Renewable Energy}

\section{Resources}

Own Your Power! A Consumer Guide to Solar Electricity for the Home

Information about solar energy systems, financial incentives, and warranties and insurance along with tips for success www.nrel.gov/docs/fy09osti/43844.pdf

\section{Small Wind Electric Systems}

A consumer's guide that provides information about small wind energy systems for rural areas, including maintenance and zoning issues www.windpoweringamerica.gov/pdfs/ small_wind/small_wind_guide.pdf

\section{Geoexchange}

A Web site from the Geothermal Heat Pump Consortium that presents information about geothermal heating and cooling www.geoexchange.org

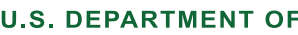

\section{ENERGY}

\section{Energy Efficiency \& Renewable Energy}

EERE Information Center 1-877-EERE-INF (1-877-337-3463) eere.energy.gov/informationcenter Prepared by the National Renewable Energy Laboratory (NREL), a national laboratory of the U.S. Department of Energy, Office of Energy Efficiency and Renewable Energy; NREL is operated by the Alliance for Sustainable Energy, LLC.

This document is one in a series of documents outlining the options for and benefits of rebuilding green after a disaster. The series draws on lessons learned by teams from the U.S. Department of Energy and its National Renewable Energy Laboratory as they helped the townspeople of Greensburg, Kansas, rebuild green after a devastating tornado. To see the other documents in this series, visit www. buildings.energy.gov/greensburg/.

DOE/GO-102009-2767 • October 2009

Printed with a renewable-source ink on paper containing at least $50 \%$ wastepaper, including $10 \%$ post consumer waste. 